\title{
GU(U)AM - SZANSA NA DYWERSYFIKACJĘ DOSTAW ZASOBÓW ENERGETYCZNYCH DO EUROPY
}

Doczatki regionalnej organizacji, zrzeszającej Gruzję, Ukrainę, spotkania we Wiedniu dotyczącego Porozumienia ws konwencjonalnych sit zbrojnych $w$ Europie ${ }^{1}$. Wtedy też po raz pierwszy mamy do czynienia ze wspólnymi oświadczeniami i inicjatywami przedstawicieli Gruzji, Ukrainy i Mołdawii. Kolejnym etapem prowadzącym do zacieśnienia współpracy między późniejszymi członkami GUUAM-u (swoją nazwę bierze od pierwszych liter krajów tworzących) był szczyt Rady Europy w

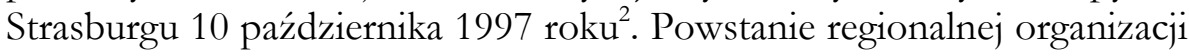
GUUAM było w pewnym sensie odpowiedzią ze strony państw, wchodzących później w jej skład, na aktywność integracyjną Rosji na terenie WNP, a konkretnie na Układ Rosji z Białorusia, zakładający daleko idącą integrację tych dwóch krajów.

W dniu 24 kwietnia 1999 roku na szczycie NATO w Waszyngtonie do GUAM przyłączył się Uzbekistan (wówczas nazwa zmieniła się na GUUAM). Wtedy też po raz pierwszy zostały sformułowane cele tej organizacji. Współpraca w ramach GUUAM miała dotyczyć wspólnych działań państw na forum organizacji międzynarodowych. Decydującym, jeżeli chodzi o formalno-prawny kształt organizacji był szczyt państw członków tej organizacji w 2000 roku w Jałcie. Na szczycie jałtańskim GUUAM zostało formalnie przekształcone $\mathrm{z}$ forum państw w organizację międzynarodową $\mathrm{z}$ własnymi organami oraz statutem. Najwyższym organem stało się

${ }^{1}$ ГУУ АМ: реалї і перспективи (аналітична доповідъ УЦЕПА), „Національна безпека і оборона", 2001, nr 7;

http://www.uceps.org/ua/section/National_Security_and_Defence/?cur_nomer=19, 16.05.2005.

2 Oficjalny portal organizacji GUUAM: http://www.guuam.org/general/browse.html, 06.01.2006. 
coroczne „spotkanie przywódców piatki państw”, wykonawczym organem są ,posiedzenia ministrów spraw zagranicznych”, a roboczym „komitet narodowych koordynatorów”. Na szczycie zostały ustalone konkretne dziedziny współpracy między krajami. Analitycy podkreślają odejście w tym czasie przez państwa GUUAM od priorytetów wojskowo-politycznych deklarowanych na początku. Przyszła współpraca miała dotyczyć głównie gospodarczych i socjalnym aspektów.

Od samego początku istnienia regionalnej organizacji było kilka koncepcji rozwojowych wewnattrz porozumienia. Ukraina i Gruzja opowiadały się za ściślejszą współpracą we wszystkich dziedzinach, w tym wojskowości i bezpieczeństwa. Azerbejdżan, Mołdawia i Uzbekistan proponowały się skupić na gospodarce, energetyce oraz polityce socjalnej.

Moim zdaniem, aby unaocznić istniejące przeszkody i perspektywy dla rozwoju współpracy regionalnej w ramach GUUAM, należy przeanalizować najważniejsze płaszczyzny kooperacji państw członków tej regionalnej struktury. Bez wątpienia najważniejszymi dziedzinami, na które warto zwrócić uwage sa wymiana handlowa, kwestie energetyczno-surowcowe oraz współpraca wojskowa i polityczna.

Siłę każdego międzynarodowego porozumienia, zakładającego współpracę gospodarczą można dość łatwo ocenić, porównując procentowy udział członków w eksporcie i imporcie każdego z krajów porozumienia. Dla przykładu udział wszystkich krajów GUUAM w eksporcie Ukrainy na rok 2001 wyniósł zaledwie - 2,53\%, w imporcie zaś $-1,77 \%{ }^{3}$. Podobnie sytuacja wygląda w pozostałych krajach organizacji. Głównymi przyczynami niezadowalającej współpracy gospodarczej w ramach organizacji sa bez wattpienia stan gospodarki (odziedziczony po rozpadzie ZSRR) oraz niski poziom inwestycji bezpośrednich. Kolejna kwestia, hamująca rozwój wymiany handlowej w ramach GUUAM jest brak priorytetowego traktowania członków tej organizacji przez uczestników porozumienia. Po przeprowadzonych badaniach przez Analityczny Ośrodek im. O. Razumkowa w Kijowie wśród ekspertów ukraińskich oraz społeczeństwa państwa GUUAM zajmuja szóste bądź ósme miejsce w priorytetach współpracy zagranicznej Ukrainy (po Unii Europejskiej, USA, Związku Rosji i Białorusi, Radzie Europy, NATO, WNP oraz ONZ) ${ }^{4}$.

\footnotetext{
${ }^{3}$ ГУУ АМ: реалї̈ і перспективи (аналітична доповідь УЦЕПА), dz. суt.

${ }^{4}$ Tamże.
} 
Perspektywa kooperacji gospodarczej pozostają kwestie energetyczne oraz inwestycje z nimi związane. Właśnie płaszczyzna energetyczna jest wymieniana przez większość ekspertów jako jedna z najbardziej realnych możliwości regionalnej współpracy między członkami GUUAM. Patrząc na mapę zauważamy, iż zaczynając od Uzbekistanu poprzez Azerbejdżan, Gruzję oraz dalej przez Morze Czarne na Ukrainę i Mołdawię tworzy się korytarz dla transportu surowców z Azji poprzez Kaukaz i Ukrainę do Europy Środkowej i Zachodniej. Opisany szlak pokrywa się z globalnym projektem transportowym wspieranym przez Unię Europejską TRACECA (Transport Corridor Europe-Caucasus-Asia). Wspomniany projekt zakłada odbudowę nowego szlaku transportowego, nawiązującego do historycznego „szlaku jedwabnego”, który spełniał bardzo ważną rolę w przeszłości ${ }^{5}$.

Korytarz transportowy GUUAM zakłada przesył ropy z Morza Kaspijskiego do Azerbejdżanu, następnie do gruzińskich portów, skąd tankowcami ropa naftowa miałaby trafiać do Odessy. Z ukraińskiego portu natomiast, rurociagiem Odessa-Brody, nafta trafiałaby do granicy z Polską, a dalej miałaby być transportowana do Gdańska (w przypadku przedłużenia rurociagu Odessa - Brody do Gdańska) oraz na Słowację i do kilku innych państw zainteresowanych dywersyfikacją dostaw surowców energetycznych. Właśnie zmniejszenie zależności energetycznej od Federacji Rosyjskiej było od samego początku jednym z ważniejszych aspektów przemawiającym za realizacją „kaukaskiego korytarza energetycznego”. Większość państw WNP jest uzależniona w znacznym stopniu od dostaw surowców z Rosji. Jedynym dotychczas zrealizowanym projektem w celu transportu surowców energetycznych z basenu Morza Kaspijskiego jest ropociag z Baku do gruzińskiego miasta Supsa, skąd tankowcami ropa przewożona jest do Odessy ${ }^{6}$.

Jak każdy znaczący projekt globalny, również korytarz transportowy GUUAM jest uzależniony od poparcia najważniejszych geopolitycznych graczy. USA, jedyne supermocarstwo pozostające na mapie politycznej świata, prowadzi aktywną politykę energetyczną na całym świecie. Jednym z priorytetowych kierunków takiej polityki jest właśnie basen Morza Kaspijskiego. Najważniejszymi założeniami wspomnianej polityki USA są: zabezpieczenie dostaw ropy z basenu

5 A. Głąb, Rola Federacji Rosyjskiej $w$ polityce Kirgizji, http://psz.pl/content/view/1299/30/,06.01.2006.

${ }^{6}$ G. Akko, Czy Ukraina jest krajem o newralgicznym znaczeniu dla Polski?, „Polish News”, http://www.polishnews.com/text/politics/czy_ukraina_jest_krajem_o_newralgicznym _znaczeniu_dla_polski.html, 06.01.2006. 
Morza Kaspijskiego do Stanów Zjednoczonych (alternatywa dla złóż z Bliskiego Wschodu) i przeciwdziałanie dominacji Rosji w tym regionie oraz blokowanie inicjatyw irańskich. W dniu 25 maja 2005 roku został uruchomiony rurociag BTC (Baku - Tbilisi - Ceyhan) z Azerbejdżanu do Turcji goraco wspierany przez kierownictwo Białego Domu. Wspomniany rurociag zmniejszył udział Rosji w dostarczaniu surowców, stworzył alternatywę dla surowców z Bliskiego Wschodu ${ }^{7}$. Jak widać główne cele USA zostały już osiagnięte poprzez uruchomienie rurociagu prowadzącego z Azerbejdżanu do Turcji. Jakie, w takim razie, możliwości pozostają dla inicjatywy GUUAM i „korytarza kaukaskiego”? Otóż transport surowców korytarzem kaukaskim może być uzupełnieniem wspomnianego rurociagu Baku - Tbilisi - Ceyhan a nie konkurencją dla niego. Najważniejszym zadaniem jednak pozostaje znalezienie wystarczającej liczby odbiorców z jednej strony (mam głównie na uwadze państwa Europy Środkowej oraz Bałkany) i zapewnienie zadowalającej ilości ropy ze złóż kaspijskich.

Kolejną ważną kwestia jest stosunek zachodnich firm wydobywających ropę naftową ze złóż basenu kaspijskiego do transportu ropy korytarzem GUUAM. W rzeczywistości właśnie zachodnie koncerny takie jak amerykański Chevron i brytyjski British Petroluem, a nie rządy poszczególnych krajów regionu Morza Kaspijskiego mają decydujący wpływ na decyzję o transporcie ropy. Zabieganie o poparcie inicjatywy GUUAM z boku zarządów wspomnianych korporacji i nieustanne promowanie przedsięwzięcia wydaję się być niezbędnym elementem dla ewentualnego powodzenia transportowego projektu w przyszłości.

Stosunek Unii Europejskiej jako planowanego odbiorcy ropy naftowej płynącej „korytarzem kaukaskim” od dłuższego czasu był dosyć ostrożny i niejednoznaczny. Wydaje się jednak, że po ostatnim rozszerzeniu o 10 krajów sytuacja może się zmienić na korzystniejszą. W Unii Europejskiej znalazła się bowiem grupa krajów Europy ŚrodkowoWschodniej, która będzie o wiele bardziej zainteresowana powodzeniem „kaukaskiego korytarza”.

Jednym z największych przeciwników całego przedsięwzięcia związanego z transportem surowców przez terytorium państw-członków GUUAM pozostaje Federacja Rosyjska. Od samego początku władze w Moskwie starały się zablokować oraz dyskredytować inicjatywę GUUAM. Powodzenie całego projektu wraz z uruchomieniem

\footnotetext{
7 PAP, Azerbejdżan: uruchomiono naftociag Baku - Ceyhan, „Gazeta Wyborcza”, 15.05.2005; http://serwisy.gazeta.pl/swiat/1,34300,2729874.html, 06.01.2006.
} 
alternatywnych szlaków zaopatrzenia w surowce energetyczne osłabiłoby znacznie wpływy Kremla na obszarze WNP oraz znacznie zmniejszyłoby monopol Rosji w dostarczaniu ropy z Azji do Europy. Federacja Rosyjska podjęła kilka kroków skutecznie blokujących inicjatywę GUUAM. W 2004 roku został dokończony kolejny rurociag z Kazachstanu do portu w Rosji: Tengiz - Noworosyjsk ${ }^{8}$. Istnienie kilku poważnych projektów inwestycyjnych (tj. rurociąg z Azerbejdżanu do Turcji BTC oraz wspomniany Tengiz - Noworosyjsk) w regionie Morza Kaspijskiego moga w niedalekiej przyszłości zabezpieczyć transport całości wydobywanej ropy, skazując tym samy na niepowodzenie inicjatywę GUUAM. Kolejnym krokiem było podpisanie umowy Rosji z Ukrainą o wykorzystaniu rurociagu Odessa - Brody przez rosyjskie firmy w odwrotnym kierunku do zamierzonego, czyli z rurociagu „Przyjaźń” na terytorium Ukrainy ropa trafiałaby w Brodach do ropociagu Odessa Brody i jest pompowana do portu w Odessie.

Po wejściu 10 nowych członków do Unii Europejskiej, jak już wspominałem, interes do przedłużenia rurociagu Odessa - Brody dalej do Europy znacząco się zwiększył. Obecnie trwają prace szacunkowe na terenie Polski finansowane przez UE w celu ustalenia opłacalności przedsięwzięcia. Zmiana sytuacji politycznej na Ukrainie oraz ostatnia wojna gazowa między Kijowem i Moskwa prorokują intensyfikację prac nad dywersyfikacją źródeł zaopatrzenia w surowce energetyczne krajów europejskich. Wygląda na to, że obecnie jest jeden $z$ najlepszych koniunkturalnie momentów dla władz nad Dnieprem do wykorzystania ostatnich wydarzeń na europejskim rynku energetycznym w celu udowodnienia partnerom na zachodzie Europy znaczenia energetycznego uzależnienia od Rosji. Zachowanie Gaðpromu tylko utwierdza w przekonaniu, że coraz częściej Kreml będzie sięgał do polityki szantażu i nacisków politycznych przy pomocy surowców energetycznych.

Kolejną ważną płaszczyzną współpracy GUUAM jest kooperacja w sferze politycznej i wojskowej. Po powołaniu w 1997 roku GUAM obserwujemy znaczący wzrost kontaktów między krajami porozumienia. W ciagu kilku lat mogliśmy obserwować wspólne inicjatywy krajów GUUAM i deklaracje $\mathrm{w}$ ramach działania w takich organizacjach jak ONZ czy Rada Europy. Znacząca aktywność w kontaktach politycznych nie przekłada się jednak na osiagnięcia w sferze gospodarczej. Jeżeli chodzi o kwestie współpracy militarnej to już na samym początku

8 A. Loskot, BTC a sprawa kazaska, komentarze Ośrodka Studiów Wschodnich, 02.06.2005; http://www.osw.waw.pl/pub/koment/2005/06/050602c.htm, 06.01.2006. 
zaznaczyłem różnice zdań poszczególnych członków GUUAM. Najważniejszymi orędownikami poszerzenia takiej współpracy pozostaja Gruzja i Ukraina. Podczas jałtańskiego szczytu założycielskiego GUUAM nie udało się jednak przeforsować wpisania do statutu możliwego wówczas przekształcenia GUUAM w organizację o charakterze militarnym. Taką inicjatywę skutecznie zablokowały Uzbekistan i Azerbejdżan. Kolejną przyczyną hamującą rozwój kooperacji wojskowej między krajami, jest obecność baz rosyjskich na terytorium Gruzji, Azerbejdżanu i Mołdawii?.

Mimo odseparowania od samego początku militarnej sfery kooperacji doszło jednak do kilku ciekawych inicjatyw wewnattrz regionalnego porozumienia. Pierwsza z takich inicjatyw była próba utworzenia wojskowej formacji dla monitorowania bezpieczeństwa na obszarze wzdłuż korytarza energetycznego. Inicjatywa wspomniana wyżej nie została zrealizowana, gdyż spotkała się z dosyć chłodnym przyjęciem Mołdawii, Uzbekistanu, a nawet Gruzji. Kolejną inicjatywa była propozycja współpracy NATO - GUUAM. Pakt Północnoatlantycki nie poparł tej propozycji, albowiem uznał, że preferuje współpracę w ramach Partnerstwa dla pokoju z każdym z krajów GUUAM z osobna. Ostatecznie kooperacja militarna sprowadziła się do handlu i modernizacji uzbrojenia oraz do uczestniczenia w ćwiczeniach organizowanych przez Sojusz Północnoatlantycki.

Po przeanalizowaniu kilku lat istnienia tej regionalnej organizacji można bez większych trudności stwierdzić, iż od 1997 roku nie notuje się spektakularnych sukcesów odniesionych przez GUUAM. Współpraca gospodarcza, polityczna i militarna nie przyniosła pożądanych efektów i nie wyszła poza ramy bardzo optymistycznych i obiecujących deklaracji. Do jednego $z$ nielicznych rezultatów działalności GUUAM można zaliczyć ukończenie rurociagu Odessa - Brody, sfinansowanego przez stronę ukraińską. Nie należy jednak nie doceniać tego przedsięwzięcia, bowiem stworzone zostały gruntowny podstawy dla kontynuacji prac nad „korytarzem energetycznym”.

Po „kolorowych rewolucjach” w Gruzji i na Ukrainie oraz po reorientacji Mołdawii w stronę Zachodu, mamy do czynienia w pewnym sensie z „reaktywacja” GUUAM-u. Potwierdzeniem tego postulatu jest ostatni szczyt GU(U)AM ${ }^{10}$ w Kiszyniowie (22 kwietnia 2005 roku).

\footnotetext{
9 ГУУ АМ: реалї̈ і перспективи (аналітична доповідь УЦЕПА), dz. суt.

10 Nazwa GUUAM straciła literę U po zawieszeniu członkostwa w tej organizacji przez Uzbekistan w 2002 roku. Ostatecznie Uzbekistan wyszedł ze składu GUUAM w 2005

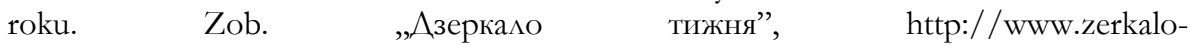
nedeli.com/nn/show/544/49976/
} 
Kluczowym pytaniem tego szczytu miał być „konflikt naddniestrzański” i możliwe sposoby rozwiązania. Głównym tematem rozmów był ukraiński plan uregulowania konfliktu w ,zbuntowanym” regionie Mołdawii.

W materiale Jacka Wróbla pracownika Ośrodka Studiów Wschodnich czytamy: „Kijów zaproponował demokratyzację reżimu naddniestrzańskiego, wprowadzenie do negocjacji naddniestrzańskich w charakterze mediatorów UE i USA oraz zastapienie obecnego kontyngentu sił pokojowych zdominowanego przez Rosję kontyngentem międzynarodowym pod egidą OBWE. Kijów zgodził się na wprowadzenie obserwatorów OBWE na naddniestrzański odcinek granicy ukraińsko-mołdawskiej i zaproponował rozpoczęcie międzynarodowego monitoringu naddniestrzańskich zakładów przemysłu zbrojeniowego (separatystyczna republika jest powszechnie podejrzewana o nielegalny handel bronia). Szczególy planu ukraińskiego mają zostać ujawnione w ciagu trzech tygodni" ${ }^{11}$.

W dużej mierze powodzenie przedstawionego planu będzie zależało od pozycji Rosji, gdyż mając swój kontyngent wojskowy na terenie Naddniestrza ma bardzo ważną kartę przetargową w tym sporze.

Po zmianach politycznych w państwach porozumienia GUUAM ma szanse wykonywać swoje cele statutowe z większym powodzeniem, napełniając je czasami zupełnie inna treścią. Ukraina próbuje od dłuższego czasu utwierdzić się w roli lidera regionalnego. Powołanie do życia GUUAM oraz Czarnomorskiej Współpracy Gospodarczej tylko potwierdza te dążenia. Władze w Kijowie próbują zrobić wszystko, co jest możliwe, żeby Ukraina pozostała kluczowym krajem dla tranzytu surowców energetycznych. Ostatnia inicjatywa rosyjska, mająca na celu zbudowanie rurociagu na dnie Bałtyku może zmniejszyć udział i znaczenie ukraińskich magistrali przesyłowych. W takiej sytuacji skuteczne lobbowanie wykorzystania korytarza kaukaskiego przez kraje europejskie przyczyni się do wzrostu znaczenia Ukrainy na arenie międzynarodowej. Oprócz tego Ukraina zmniejszy swoje uzależnienie energetyczne od północnego sąsiada, zwiększając tym samym swoje bezpieczeństwo energetyczne.

Ciężko przewidzieć możliwy rozwój GUUAM w najbliższych latach, wydaje się jednak, że obecnie zaistniały dogodniejsze warunki dla intensyfikacji działań wewnątrz porozumienia. Ostatni szczyt w Kiszyniowie nie przyniósł przełomowych decyzji oraz głębszej

${ }^{11} \mathrm{~J}$. Wróbel, Szczyt GUUAM w Kiszyniowie, materiały Ośrodka Studiów Wschodnich, 28.04.2005; http://www.osw.waw.pl/pub/koment/2005/04/050428.htm, 06.01.2006. 
instytucjonalizacji porozumienia. Trzy państwa z czterech, Ukraina, Gruzja i Mołdawia, maja jasne sformułowane cele na integracje ze wspólnotą euroatlantycką. W przyszłości GUUAM może stanowić platformę dla dialogu na temat wspomnianej integracji oraz być uczestnikiem Polityki sasiedztwa Unii Europejskiej. 